\title{
The Species Composition and Diversity of the Coastal Waters of Ondo State, Nigeria
}

\author{
Josef Bamidele Bolarinwa ${ }^{1}$, FASAKIN,Emman A $^{2}$, FAGBENRO,Adedapo $\mathbf{0}^{3}$
}

${ }^{1}$ Department of Fisheries Technology, Lagos State Polytechnic, P.M.B 21606, Ikeja, Lagos, Nigeria

${ }^{2}$ Department of Fisheries and Aquaculture Technolgy, Federal University of Technology.Akure. Nigeria

${ }^{3}$ Department of Fisheries Technology.Federal University of Technology,Akure.Nigeria

bolabolero@yahoo.com

Abstract: A study of the icthyofauna resources of the coastal waters of Ondo State of Nigeria conducted for 18 months (June 2011-December, 2012) revealed the presence of 67 finfish species with the clariids(especially Clarias gariepinus and Heterobranchus bidorsalis) and cichlids(especially Oreochromis niloticus and Coptodon zilli) dominating the stock accounting for $42 \%$ and $16 \%$ respectively. Other predominant families were A high 'Claroitedae'(Chrysichthys nigrodigitatus) with $9.2 \%$ contribution, 'Channidae'(Parachanna africana) with 8.7\%, Osteoglossidae (Heterotis niloticus) with 7.1\%, Gymnarchidae( Gymnarchus niloticus), Mugilidae (Mugil cephalus) and Clupeidae (Ethmalosa fimbriata). Lausanne Index of Abundance was 89.7\% while Margalef.s index( a measure of species richness) was 5.18. The Length-weight relationships of these predominant fishes showed negative allometric growth pattern. A high level of heterogeneity of stock was observed as revealed by Simpson Index and Shannon-Weiner Index of General Diversity (H i) which were 0.13 and 0.35 respectively. A lot of similarity in species composition existed as revealed by Evenness Index(E) of 0.20 and Berger-Perker Index of 0.88 . There was comparatively higher catches of fish in the dry season than the wet season probably due to reduced water volume which concentrated the fishes for easier catchability. The author recommends the need to protect the existing stock especially the monospecific families like the Osteoglosidae and Gymnarchidae through regular monitoring of the physicochemical parameters of the coastal waters which are highly susceptible to crude oil pollution, Ondo State being a crude oil-producing area. More funds should be committed by the government to researches on population dynamics and biomass estimate of our coastal waters.

Keywords: Species composition, diversity indices, coastal, allometry, Length-weight relationship, icthyofauna, predominant.

\section{INTRODUCTION}

Fish constitutes the major source of animal protein in Africa. It has the most balanced amino acid profile and its consumption cuts across cultural and religious barriers, hence the high demand for it worldwide. Twenty-one percent of global fish output is consumed by Africans despite the fact that its contribution to global output is the lowest(FAO, 2013). The fisheries resources of the nation comprise a rich diversity of finfish and shellfish found in the territorial waters, the EEZ and the inland waters. These resources can be categorized into coastal inshore(finfish), offshore(finfish), coastal artisanal(shellfish), Industrial(shellfish) and freshwater. The coastal inshore resources are dominated by coastal pelagics and inshore shell fish resources. The total land area of Nigeria is $923,728 \mathrm{sq} \mathrm{km}$ out of which $910,768 \mathrm{sq} \mathrm{km}$ is land and 13,000sq km is water(Obasohan and Oronsaye, 2005). Nigeria as a coastal state has a coastal line of $900 \mathrm{~km}$ bordering the Gulf of Guinea and a continental shelf area of 7,934 sq km. Nigeria declared a 200 nautical miles Exclusive Economic zone (EEZ) which gave an area 
of $210,900 \mathrm{~km} 2$ over which she has propertial rights for the purpose of exploiting, conserving and managing her fisheries resources.

According to CBN (2011), there was a shortfall of about 1.4 million tonnes between demand and supply of fish despite the rich and varied ichthyofauna resources.

These coastal ecosystems which were once rich in biodiversity and biological productivity (due to estuarine influence) are considered mismanaged and underutilized. There is gradual reduction in quantity and diversity of fisheries resources, thus leading to reducing catches(a threat to livelihood in the coastal areas). This is partially due to the fact that these coastal wetlands are the centre of oil-production in the Delta basin where fossil oil is exploited as a non-renewable resource to the detriment of the environment. The advent of oil exploration has so far been ecologically disastrous to aquatic life in the coastal wetlands (Olawusi-Peters and Ayo-Olalusi, 2009). Obasohan and Oronsanye (2005) reviewed the fish diversity in Nigerian freshwater bodies and identified the endemic fish species as well as those which are considered potentially endangered. Despite the importance of artisanal sector as a major contributor to the total domestic fish supply in Nigeria, the Nigerian natural lakes and wetland resources have received little attention (FDF, 2003; FDF,2015). There is poor knowledge of Nigerian aquatic ecosystem, hence the need for this present study of fish diversity, finfish species composition and distribution of the coastal wetlands of Ondo State There are few documented, scientific information on coastal waters of Nigeria in terms of species diversity, nature, distribution and relative abundance of the fauna in the thus making it difficult to assess the immense potential of the coastal waters. The ecosystems have enormous biological diversity, indicative of a healthy and productive ecosystem( Egborge,1993; AkegbejoSamson,1995; Bolarinwa,2015). The limited scientific studies of fisheries resources in the coastal waters of Ondo State coupled with the problems of poor management and conservation calls for a need for well documented and data -based researches. This study would therefore contribute to the much needed information on the species composition and diversity and relative abundance of the coastal areas of Ondo State of Nigeria. It would guide decision making in utilization, management and conservation of resources.

\section{MATERIALS AND METHODS}

\section{STUDY AREA}

The major fishing villages of Ondo State include Igbokoda, Ita-Aiyelala, Alape, Piawe, Mayin East, Mahin West, Idi-ogba, Oparoma, Aiyetoro, Alagbon, Ogogoro, Olokun. These areas fall along the coastal fringes, within the creeks and lagoons and within rivers, flood plains and forested swamps and are popular sites where fresh landings are made to be purchased by the fish mongers/traders (See Fig 1). The study areas are bounded in the east by Benin River in Edo State, in the West by Ogun State coastline and in the North by the land mass of Okitipupa and Irele local government areas in Ondo State. The study area is parallel to Nigeria South West coastline which is characterized by extensive lagoons and river delta systems. It ranges from 4 o to 6 o latitude and it is part of the approximately 670 kilometres coastline of Nigeria. The area represents a reflection of what occurs physically, morphologically and environmentally in the adjoining areas. There is a large concentration of mangrove and fresh water swamps. The area is subject to tidal flunctuations with salt water incursion, two to ten months of the year. There are three subzones viz freshwater, brackishwater and saltwater bordering the coastal swamps and creeks (See Fig 1).

The study involved collection of fin fishes from randomly selected fish landings sites of Mahin, Ode-Ugbo and Ugbo-Nla out of the fishing communities in a purposively selected Ilaje Local Government Area. The criteria for choosing Ilaje LGA was based on the high intensity of fishing activities and prominence as an administrative group. 
Fresh fish catches from four (4) boats were sampled on a monthly basis in each fish landing site for 18 months (June 2011-December, 2012). Diverse fishing gears used (depending on targeted species and size) were mainly monofilamentous gill nets $(25.4 \mathrm{~mm}-50.8 \mathrm{~mm})$ to catch migratory species and cast nets $(13 \mathrm{~mm}-50.8 \mathrm{~mm})$ for mainly the tilapias. The catches were sorted into taxonomic groups (species and families) using standard fish identification keys provided by Adesulu and Syndenham (2007); Boulenger (1916), Fish Base web site and Raji and Babatunde (2013). Personal communications with experience fisher folks on the local names of the fishes were also solicited. The fishes were subsequently counted and weighed.

Species abundance and composition at each sampling site were calculated using Species count, Lausanne Index of Abundance while the Species Diversity was calculated using Margalef.s Index(d) of taxa richness, Simpson's Index of Heterogeneity (D), Reciprocal of Simpson, Index(*Dr), Shannon-Weiner index of General Diversity(H1). The level of similarity of species composition of the sampling sites of the coastal waters was calculated using Jacard,s coeffient, Sorensen index and Eveness index

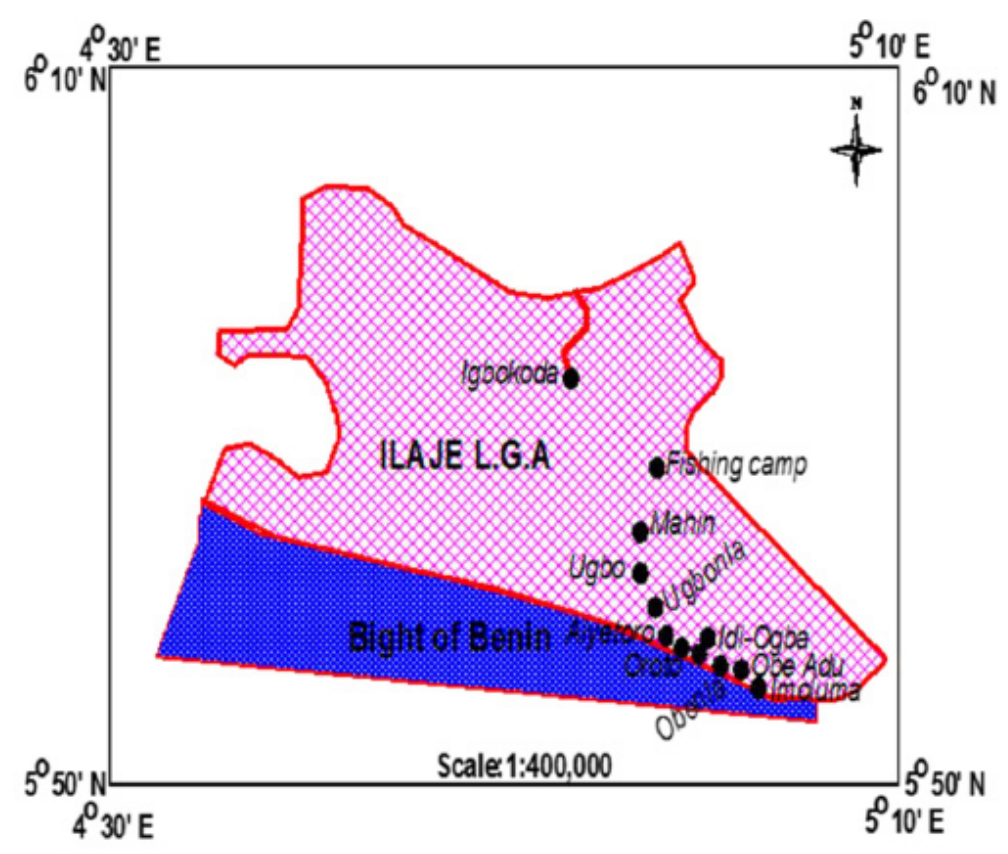

Fig2. Map of llaje L.G.A

\section{RESULTS AND DISCUSSIONS}

Table1. Diversit Indices of the Three Sampling Sites in the Coastal Waters of Ondo State, Nigeria.

\begin{tabular}{|l|l|l|l|l|}
\hline DIVERSITY INDICES & MAHIN & $\underline{\text { ODE-UGBO }}$ & UGBO-NLA & 吕OLED \\
\hline Species Count. & 65 & 58 & 57 & 67 \\
\hline Fish Abundance by No & 45,100 & 26,193 & 20,137 & \\
\hline Index of Abundance & $97 \%$ & $87 \%$ & $85 \%$ & $89.7 \%$ \\
\hline Simpson,s Index(D) & 0.137 & 0.125 & 0.121 & 0.128 \\
\hline
\end{tabular}




\begin{tabular}{|l|l|l|l|l|}
\hline$*$ Dr=N(N-1)/ ni(ni-1) & 7.29 & 8.00 & 7.78 & 7.69 \\
\hline Margalef Index & 5.69 & 4.99 & 4.86 & 5.18 \\
\hline Jaccard Index & & & & \\
\hline (Mahin \& Ode-Ugbo) & 0.86 & 0.86 & - & \\
\hline Jaccard Index & & & & \\
\hline (Mahin \& Ugbo-Nla) & 0.81 & - & 0.81 & \\
\hline Jaccard Index & & & & \\
\hline (Ode-Ugbo \& Ugbo-Nla) & - & 0.95 & 0.95 & \\
\hline Evenness Index(E) & 0.198 & 0.20 & 0.21 & 0.20 \\
\hline Sorensen,s Index & $86 \%$ & $86 \%$ & - & \\
\hline (Mahin \& Ode-Ugbo) & $86 \%$ & $86 \%$ & - & \\
\hline Sorensen,s Index & & & & \\
\hline (Mahin \& Ugbo-Nla). & \multicolumn{1}{|c|}{$81 \%$} & - & $81 \%$ & \\
\hline Sorensen,s Index & & & $97 \%$ & \\
\hline (Ode-Ugbo\& Ugbo-Nla). & - & 0.36 & 0.34 & \\
\hline Shannon-Weiner Index & 0.35 & 0.36 & 0.34 & \\
\hline of General Diversity(H I) & 0.35 & & \\
\hline
\end{tabular}

Source: Field Survey(2011-2012)

Table 1 shows that Mahin has the greatest number of finfishes by weight and number. Out of the 67 species from 36 families, Mahin had 65 species while Ode-Ugbo and Ugbo-Nla had 58 and 57 species respectively. The most predominant fish family in terms of number and weight is the family 'Clariidae', followed by families Cichlidae, Claroteidae, Channidae, Osteoglossidae, Mugilidae and Clupeidae respectively. The nine major fishes commonly found in the brackishwater area of Ondo State of Nigeria were Clarias gariepinus, Heterobranchus bidorsalis, Oreochromis niloticus, Chrysichthys nigrodigitatus, Parachanna africana, Heterotis niloticus, Gymnarchus niloticus, Mugil cephalus and Ethmalosa fimbriata. Mahin waters was richer in species diversity than Ode-Ugbo and Ugbo-Nla.

Table 1 shows that generally, Mahin waters is richer in species than Ode-Ugbo and Ugbo-Nla probably due tothe fact that there are more creeks where the hardy and predominant catfishes like the clariids and the snakeheads (Parachanna obscura and Parachanna africana) hide in Mahin than in Ode-Ugbo and Ugbo-Nla. These mud-loving catfishes are difficult to catch during the dry season because they do hibernate in holes made in muddy bottom in the creeks. Once it rains, they troop out of the vegetated areas into the open waters for oxygen where they are caught with fishing traps, set nets, hooks and lines and spears (by the more dexterious Mahin fisher folks ). Another possible reason for the higher occurrence of the fishes in Mahin might not be unconnected with the relatively fresher waters of Mahin. By virtue of the nearness of Ode-Ugbo and Ugbo-Nla to the Atlantic ocean, they have more salty waters than Mahin (Akegbejo-Samsons, 1995, Pers.comm.). Some of the fishes run away from the salty waters of Ode-Ugbo and Ugbo-Nla to the fresher water of Mahin lagoon. However, the more salt-tolerant fishes like Coptodon guineensis, Sarotherodon melanotheron, mullets and the bonga which respond with salinity occurred more during the 
higher salinity of the dry season from January-April (Bolarinwa, 1984; Agboola and Anetekhai, 2008). The onset of rainy season in May brings in young Heterotis niloticus locally called 'Pete' and the clariids.

There is also the problem of oil pollution which is more in Ugbo and Ugbo-Nla (which are oil prospecting area) coupled with more anthropogenic and industrial activities. The on-going canalization for the Natural liquefied Gas Project and Olokola Free Trade Zone might have led to destruction of breeding sites, loss of aquatic flora and fauna (Akegbejo-Samsons, 1995; Odulate, 2010). Generally, Mahin waters is richer in all the freshwater species like Heterotis niloticus, Gymnarchus niloticus, Chrysichthys nigrodigitatus, the cichlids (except Coptodon. guineensis and Sarotherodon melanotheron) apart from the clariids and the channids. Ornamental fishes like Gnathonemus spp, Red tilapia, Psettus sebae, Malapterurus electricus, Phago maculatus are more tolerant of the less saline waters of Mahin. Extraneous fishes like the Ethmalosa spp (bonga), Elops lacerta (ten-pounder) and Megalops atlanticus(tarpon) stray from the salty waters of Aiyetoro and Orioke-Iwamimo into Mahin for breeding purposes especially in June. There is higher occurrence of gravid females of Chrysichthys nigrodigitatus, Heterotis niloticus, Hepsetus odoe during the rainy months of July-October coinciding with high water volume, hence the high incidence of the young juveniles at that period. Various workers have recorded the clariids and cichlids as most dominant families in different coastal waters and reservoirs (Oboh, 2013; Adeosun, 2007; Olopade et al, 2006; Imaobong, 2012). A total number of 67 species belonging to 36 families were recorded across the three sampling sites in the brackishwater zone of Ondo State. Species count of 65 was recorded for Mahin while that of Ode-Ugbo and Ugbo-Nla were 58 and 57 respectively showing Mahin to be the most species-rich fishing site (Table 1).

The high number of species recorded in the present study did not correspond with the findings of Akegbejo-Samsons (1995) who recorded 25 species from the brackish water zone of Ondo State. Previous workers also reported lower number of fish species attributing it to extinction, pollution and overfishing. Ogaga (2012) observed 34 species as against 91 recorded previously in Warri River, Nigeria. The sharp drop in species diversity was attributed to extinction. Yem et.al (2009) reported extinction of threatened fishes and succession in Kainji Dam as a result of impoundment.

The reason for the higher abundance observed in the present study might not be unconnected with speciation due to physical, ecological and climatological barriers. A lot of earth movement and canalization for industrial projects like Olokola Free Trade Zone have been on-going over the past two years. This was confirmed by the higher value of Fish abundance by number and by weight recorded for Mahin. The Index of Abundance according to Lauzanne (1983) was highest in Mahin (98\%) followed by Ode-Ugbo (87\%) and lastly Ugbo-Nla with $85 \%$

The highest fish abundance observed in Mahin might be due to the low salinity of Mahin which waters are not as saline as that of Ode-Ugbo and Ugbo-Nla (which are closer to the salt-laden Atlantic ocean). Their nearness to salty waters of Orioke, Iwamino, Aiyetoro and other sea fishing villages might be responsible. There was a possibility of fish migration from the more saline waters of Ugbo and Ugbo-Nla to the cooler, more or less fresh waters of Mahin, hence the higher abundance of fish in Mahin.

The value of Simpson,s Index recorded for Mahin was lowest showing a high degree of heterogeneity of species composition in Mahin than the other two brackishwater sampling sites. Margalef Indices ( a measure of species Richness or Taxa Richness ' $d$ ') was also highest for Mahin .It decreased from 5.69 in Mahin to 4.86 in Ugbo-Nla, the most polluted fishing site by virtue of the oil leakages of the boat transporters at the jetty.

Diversity indices like Jaccard Coeficients, Sorensen,s Index(SI), Shannon-Weiner Index(H) and Evenness Index 
were calculated. The values showed there is a lot of similarities in species composition between Ode-Ugbo and Ugbo-Nla .

Jaccard,s coefficient was 0.81 between Mahin and Ugbo-Nla while the value calculated for Ode Ugbo and Ugbo-Nla was 0.95 , The higher value got for Ode-Ugbo and Ugbo-Nla showed similarity of the two sampling sites in terms of species composition. This corresponds with the values of Sorensen Index 'SI' ( a measure of similarities of species composition between two communities. This might not be unconnected with the almost similar value of salinity and other physicochemical parameters, the two fishing villages being near the Atlantic ocean.

Value obtained for Evenness Index (E), a ratio of observed diversity (H) to maximum diversity Hmax showed all the species are not equally abundant. This trend cuts across all the sampling sites. The maximum value of 1 shows all species are equally abundant

\section{REFERENCES}

Abass, M.A, Kumolu-Johnson,C.A and Fakoya, K.A (2010). A biotechnical assessment of the artisanal Purse seine fishery at Orimedu coastal village in Lagos State, Nigeria, Nigerian Journal of Fisheries, $7: 1$ - 2.

Adesulu, E.A and Syndenham, D,H.J (2007). The Freshwater Fishes and Fisheries of Nigeria, Mac- Millan Nigeria Publishers Limited, Ibadan, Nigeria, pp 6-130.

Agboola, J. I. and Anetekhai, M. A. (2008). Length-weight Relationships of Some Fresh and Brackish Water Fishes in Badagry Creek, Nigeria. J. Appl. Ichthyol. 24: 623-625.

Akegbejo-Samsons, Y (1995). Ecology of the Fisheries Resources of coastal wetlands of Ondo State and its management implications. Ph.D Thesis, Department of Fisheries \&Wildlife, Federal University of Technology, Akure. pp1-126.

Boulenger, G.A (1916): Catalogue of the Freshwater Fishes of Africa in the British Natural History Museum, Order of the Trustees, London, 4:392pp.

Central Bank of Nigeria (2011). Annual Technical Report on Nigerian Perspectives,vol.11(Issue 6) pp1-5.

Egborge, A.B.M (1993). Biodiversity of Aquatic fauna of Nigeria. National Resources Conservation Council, Abuja,193pp.

FAO (2013). Production Database, Food and Agriculture Organisation of the United Nations. http://faostat. fao-org/site/567/desktopDefault.spx.

FDF (2007). Fisheries Statistics of Nigeria, Federal Department of Fisheries, Abuja, Nigeria,4th Edition (1995-2007).

FDF (2015). Fisheries Statistics of Nigeria, Federal Department of Fisheries, Abuja,Nigeria,6th Edition (2010-2015).

Imaobong, E.E (2012). Assemblages of Fish species of Ikpa River in Akwa Ibom, Nigeria Proceedings of the 26th Annual Conference of Fisheries Society of Nigeria, pp 99-102 (edited by Ansa, E.J and Ndimele,P).

Obasohan,E.E and Oronsaye,J.A.O(2005). Biodiversity and Sustainability of Freshwater fishes in Nigeria, Proceedings of the Annual Conference of Fisheries Society of Nigeria, pp 56-599 (Editors: Araoye,P and Omoniyi,I.T). 
Oboh, A, Dan-Kishiya, A.S (2013). Fisheries resources and Developmental Potentials of Usuma River in Gwagwalada, Abuja, 27th Conference of Annual Conference of Fisheries Society of Nigeria(edited by Ansa,E.J. and Ndimele,P.).

Odulate,D.O (2010). Diversity and Growth Parameters of Fish population in Ode-Omi marine front of Ogun State, Nigeria, Ph,D Thesis, University of Agriculture, Abeokuta, Nigeria, pp5-112.

Ogaga, A.A(2012). Fish species composition, Diversity of Warri River, Niger Delta, Proceedings of the 26th Annual Conference of Fisheries Society of Nigeria, pp132-134.(edited by Ansa,E,J and Ndimele,P).

Olawusi-Peters, 0.0 and Ayo-Olalusi, C.I(2009). Finfish diversity in Agboyi Creek, Lagos State of Nigeria. Proceedings of the Conference of Fisheries Society of Nigeria, 244-247pp (edited by Araoye, P.A and Omoniyi. I.T).

Olopade, J.O and Tarawallie, S(2014). The Length-weight Relationship, condition factor and Reproductive Biology of Pseudotolithus senegalensis (Valenciennes,1833) in Tombo Western Rural District of Sieraleone, African Journal of Food, Agriculture, Nutrition and Development,14(6): 2176-2188.

Yem, I.Y, Bankole,O.N and Ibrahim, A(2013). Fish Species succession and disappearance in Kainji Lake, Nigeria. 27th Conference of Annual Conference of Fisheries Society of Nigeria, pp123.(edited by Ansa, E and Ndimele,P)

Citation: Josef Bamidele Bolarinwa, FASAKIN,Emman A, FAGBENRO,Adedapo 0, The Species Composition and Diversity of the Coastal Waters of Ondo State, Nigeria. ARJA Volume 2016; pp:1-7

Copyright (c) 2016 Josef Bamidele Bolarinwa. FASAKIN,Emman A, FAGBENRO,Adedapo 0, This is an open access article distributed under the Creative Commons Attribution License, which permits unrestricted use, distribution, and reproduction in any medium, provided the original work is properly cited. 